PRODUCTION

ENGINEERING ARCHIVES
2014, Vol. 3, No 2, pp 6-9

ISSN 2353-5156

ISSN 2353-7779 (print version)

(online version)

Article history: $\quad$ Received: 10.04.2014

Accepted: 12.05.2014

Online: 31.07 .2014

\title{
The influence of modification for structure and impact resistance of silumin AlSi11
}

\author{
Remigiusz Romankiewicz ${ }^{1}$, Ferdynand Romankiewicz ${ }^{2}$ \\ ${ }^{1}$ University of Zielona Góra, Licealna 9 65-417, Poland, +48683282517, +48683282620, r.romankiewicz@ibem.uz.zgora.pl \\ ${ }^{2}$ University of Zielona Góra, Licealna 9 65-417, Poland, +48683282516, +48683282620, f.romankiewicz@ ibem.uz.zgora.pl
}

\begin{abstract}
In this paper the results of the modification process of alloy AlSi11 as well as the influence of modification for structure and impact resistance have been presented. The investigation revealed that the modification of the AlSil1 silumin with the addition $0,05-0,4 \%$ AlSr10 and $0,1-0,2 \%$ AlB4 simultaneously provided the advantageous refinement of the $\alpha$-phase as well as the change of the morphology of the eutectic silicon from the lamellar into the fibrous one. The change resulted in a relevant increase in the impact resistance of the alloy and the widening of the plastic area of the fracture of the silumin samples.
\end{abstract}

Key words - silumin, modification, fracture

\section{Introduction}

The structure and the mechanical properties of AlSi11 alloy may be improved through applying thermal treatment or a simple technological modification with suitable micro-additives. To achieve the advantageous state of the structure of AlSi11 alloy requires a modifying process involving refinement of the $\alpha$ phase crystals as well as changing the morphology of the eutectic silicon from lamellar into fibrous (PONIEWIERSKI Z. 1989, MÜLLER K. 1995, WASILEWSKI P. 1995, PIETROWSKI S. 2001, TILLOVÁ E., ĎuriníKOVÁ E., CHALUPOVÁ M., RADEK N. 2014).

The authors have tried to modify AlSi11 alloy applying AlB4 master alloy to refine the $\alpha$ phase crystals, whereas AlSr10 master alloy is used to refine the eutectics. It has been recognized that it is necessary to investigate the influence of modification of AlSi11 silumin on its structure and morphology of fractures in an impact resistance test.

\section{Description of the experiments \\ 2.1. Melting and modification of AlSi11 alloy}

The experiments were carried out for the AlSi11 technical alloy, of the chemical composition: $12,04 \%$ $\mathrm{Si} ; 0,57 \% \mathrm{Fe} ; 0,24 \% \mathrm{Cu} ; 0,20 \% \mathrm{Mg} ; 0,13 \% \mathrm{Mn}$; $0,04 \% \mathrm{Ni} ; 0,03 \% \mathrm{Zn} ; 0,02 \% \mathrm{Ti}, \mathrm{Zr}$; rest Al. The melting process and the modification were carried out in a graphite-chamotte melting crucible in a resistance furnace chamber.

The modification process was carried out while overheating the metal bath to a temperature of $1003 \mathrm{~K}$ $\left(730^{\circ} \mathrm{C}\right)$. The modifying additives included AlB4 and AlSr10 master alloys. They were applied separately 
and in combinations. The modification process lasted 10 minutes. The modification conditions as well as the results of the experiments are presented in Table 7.1.

\subsection{The results of the experiments}

The influence of the modification on the change of the structure of AlSil1 silumin is presented in Fig. 7.1a-7a and the influence of modification for fracture morphology is presented in Fig. 7.1b-7b.

It shows that the alloy in a non-modified state (Fig. 7.1a) reveals lamellar precipitation of eutectic silicon as well as big $\alpha$ phase crystals. The additives of the AlSr10 master alloy in the amounts $0,2 \%$ (Fig. 7.2a) caused very significant change in morphology of the eutectic silicon. The additives of the AlSr10 master alloy changed the morphology of the eutectic silicon in a very favourable way, providing its fibrous form.

a)

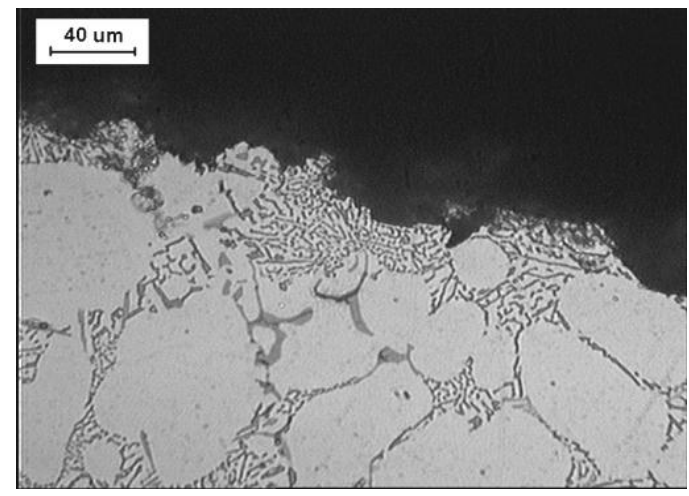

b)

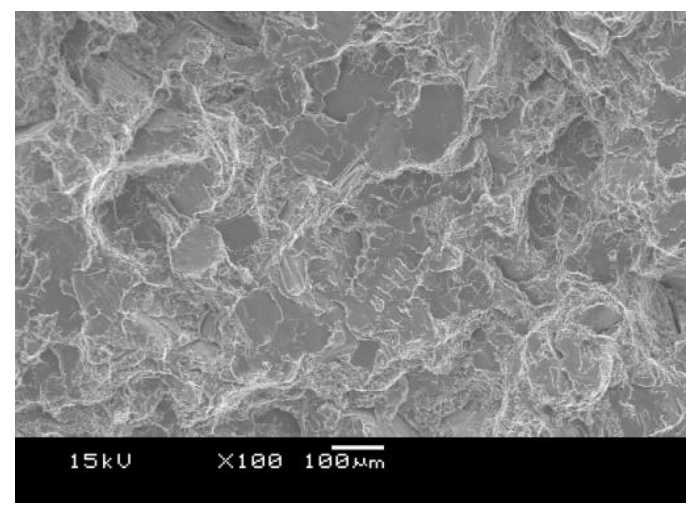

Fig. 7.1. Structure of the profile of the fracture of AlSil1 alloy without modification: a) profile of the fracture $(O M), b)$ morphology of the fracture (SEM)

Source: own study. a)

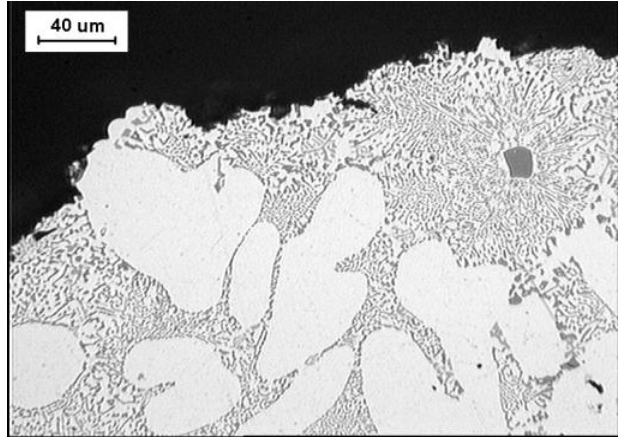

b)

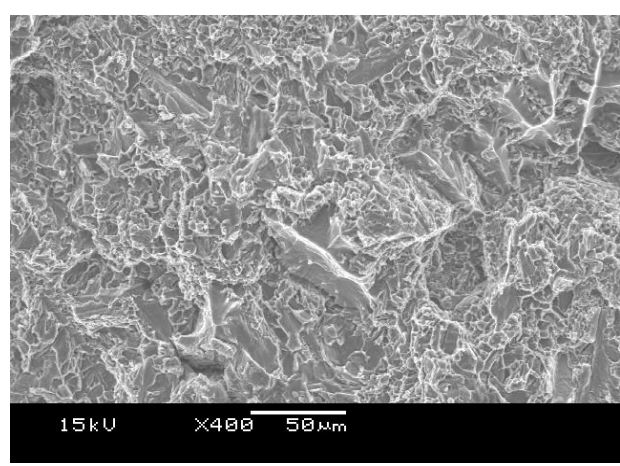

Fig. 7.2. Structure of the profile of the fracture of AlSil1 alloy modified with 0,2\% AlSr10: a) profile of the fracture $(O M), b)$ morphology of the fracture (SEM) Source: own study.

a)

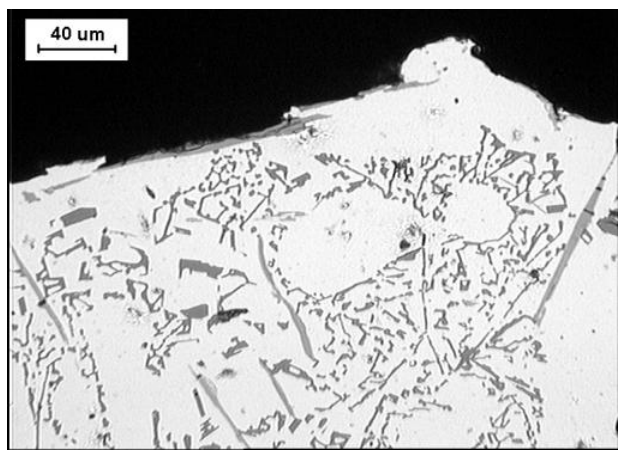

b)

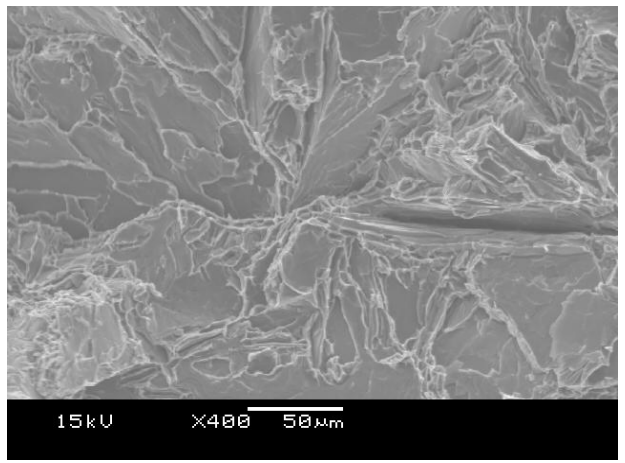

Fig. 7.3. Structure of the profile of the fracture of AlSil1 alloy modified with 0,2\% AlB4: a) profile of the fracture $(O M), b)$ morphology of the fracture (SEM)

Source: own study. 
a)

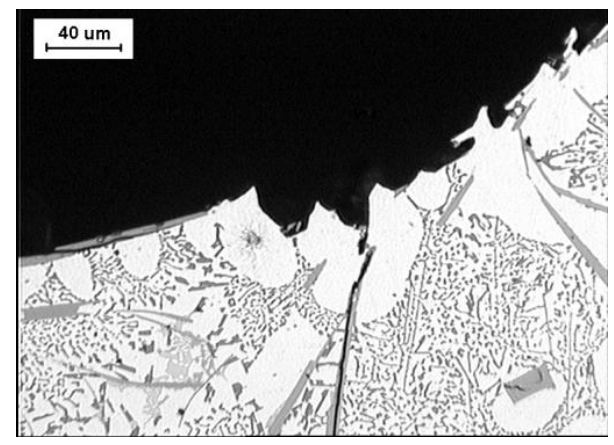

b)

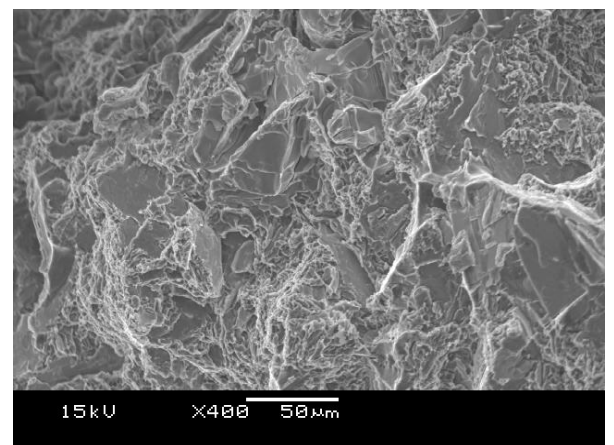

Fig. 7.4. Structure of the profile of the fracture of AlSill alloy modified with 0,05\% AlSr 10 and 0,10\% AlB4: a) profile of the fracture $(O M), b)$ morphology of the fracture (SEM)

Source: own study.

a)

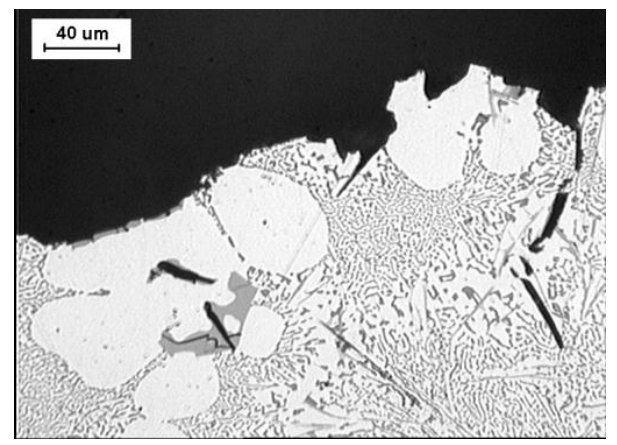

b)

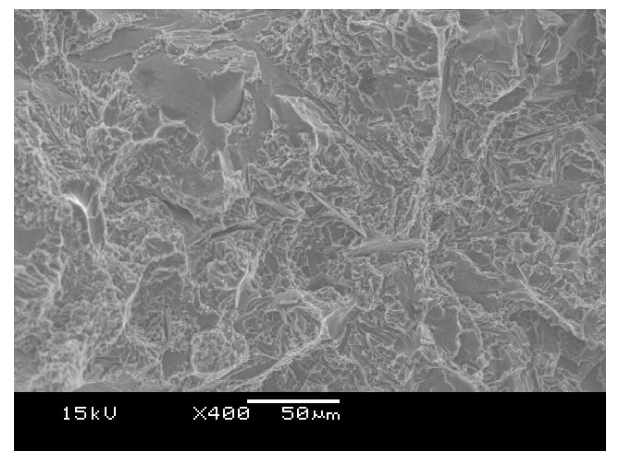

Fig. 7.5. Structure of the profile of the fracture of AlSill alloy modified with $0,10 \%$ AlSr10 and 0,10\% AlB4: a) profile of the fracture (OM), b) morphology of the fracture (SEM)

Source: own study
It shows that the refinement of the eutectics with the $\mathrm{AlSr} 10$ as a modifying additive has been proven effective, particularly for $0,2 \%$ of the additive. The use of $0,2 \%$ AlB4 master alloy (Fig. 7.3a) did not cause any changes for the eutectic silicon. Positive effects of the change of the structure have been achieved in the complex modification of the AlSi11 alloy with additives 0,05-0,4\% AlSr10 and 0,1-0,2\% AlB4 (Fig. 7.4a8a).

a)

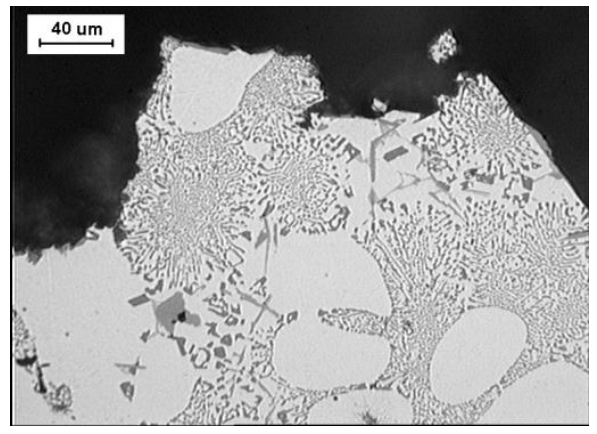

b)

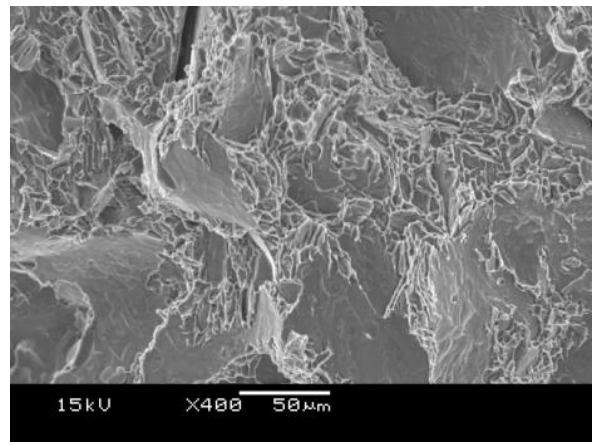

Fig. 7.6. Structure of the profile of the fracture of AlSill alloy modified with 0,15\% AlSr10 and 0,10\% AlB4: a) profile of the fracture (OM), b) morphology of the fracture (SEM)

Source: own study.

The observed changes of the structure of the AlSi11 alloy are consistent with the results of the impact resistance tests (Tab. 7.1). The non-modified alloy revealed the impact resistance amounting to $6,1 \mathrm{~J} . \mathrm{cm}^{2}$. The modification of the alloy with the additive $0,2 \%$ AlSr10 (cast 2) provided the increase in the resistance to the level $22,3{\mathrm{~J} . \mathrm{cm}^{-2}}^{2}$ reaching the highest value of the impact resistance of tested alloy. 
a)

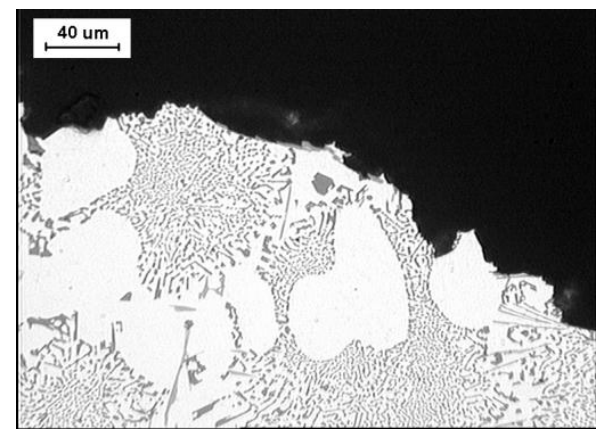

b)

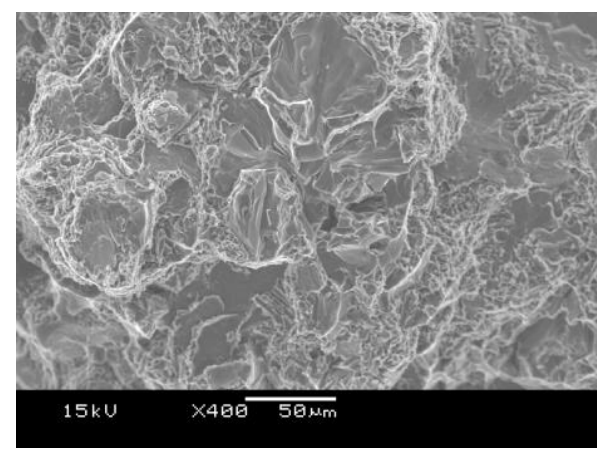

Fig. 7.7. Structure of the profile of the fracture of AlSill alloy modified with $0,4 \%$ AlSr 10 and $0,2 \%$ AlB4:

a) profile of the fracture $(O M)$, $b$ ) morphology of the fracture (SEM)

Source: own study.

Table 7.1. The influence of the modification process of the AlSill impact resistance

\begin{tabular}{|c|l|c|}
\hline $\begin{array}{c}\text { Cast } \\
\mathbf{N r}\end{array}$ & Modifications conditions & $\begin{array}{l}\text { Impact } \\
\text { resistance } \\
\text { (J.cm-2) }\end{array}$ \\
\hline $\mathbf{1}$ & non-modified & 6,1 \\
\hline $\mathbf{2}$ & modified with 0,2\% AlSr10 & 22,3 \\
\hline $\mathbf{3}$ & modified with 0,2\% AlB4 & 7,3 \\
\hline $\mathbf{4}$ & $\begin{array}{l}\text { modified with 0,05\% AlSr10 } \\
\text { and 0,10\% AlB4 }\end{array}$ & 11,9 \\
\hline $\mathbf{5}$ & $\begin{array}{l}\text { modified with 0,10\% AlSr10 } \\
\text { and 0,10\% AlB4 }\end{array}$ & 14,1 \\
\hline $\mathbf{6}$ & $\begin{array}{l}\text { modified with 0,15\% AlSr10 } \\
\text { and 0,10\% AlB4 }\end{array}$ & 15,2 \\
\hline $\mathbf{7}$ & $\begin{array}{l}\text { modified with 0,4\% AlSr10 and } \\
0,2 \% \text { AlB4 }\end{array}$ & 17,3 \\
\hline
\end{tabular}

Source: own study.

The use of $0,2 \%$ AlB4 master alloy (cast 3) did not cause a significant increase of the impact resistance. The complex modification with $0,05 \%$ AlSr10 and $0,1 \%$ AlB4 resulted in a doubling of the impact resistance $(11,9 \mathrm{~J} . \mathrm{cm}-2)$ of the alloy (cast 4$)$ in comparison to non-modified state. The further increase in the amount of AlSr10 master alloy and AlB4 master alloy caused another increase of the resistance of AlSi11 alloy reaching 15,2 J.cm-2 (cast 6) and 17,3 J.cm-2 (cast7).

\section{Summary}

The investigation revealed that the modification of the AlSi11 silumin with the additives $0,2 \%$ AlSr10 as well as the complex modification with $0,05-0,4 \%$ AlSr10 and 0,1-0,2\% AlB4 simultaneously provided an advantageous refinement of the $\alpha$ phase crystals and a change in the morphology of the eutectic silicon from a lamellar into a fibrous one. The change resulted in a doubling of the impact resistance of the alloy and a widening of the plastic area of the fracture of the silumin samples.

\section{Literature}

1. MÜLlER K. 1995. Doktor - Ingenieur Dissertation. TU Berlin. Berlin.

2. PIETRowski S. 2001. Siluminy. Politechnika Łódzka. Łódź.

3. PONIEWIERSKI Z. 1989. Krystalizacja, struktura $i$ wtaściwości siluminów. WNT. Warszawa.

4. Tillová E., ĎuriníkOvÁ E., Chalupová M., RADEK N. 2014. Effect of laser surface treatment on the quality of microstructure in recycled Al-Zn-Si cast alloy. Production Engineering Archives, Vol. 2(1)/2014

5. WASILEWSKI P. 1995. Siluminy - modyfikacja $i$ jej wptyw na strukturę $i$ właściwości. Nr 21. In: Krzepnięcie metali i stopów. Komisja Odlewnictwa PAN. Katowice. 